\title{
ADDITIVITY OF CONFORMATIONAL ENERGY: QUANTUM MECHANICAL INVESTIGATION OF FLUORO- AND BROMOALKANES
}

\author{
R. Jankauskas, P. Pipiraitè, and D. Šatkovskienè \\ Department of Theoretical Physics, Faculty of Physics, Vilnius University, Saulètekio 9, LT-10222 Vilnius, Lithuania \\ E-mail: dalia.satkovskiene@ ff.vu.lt
}

Received 31 May 2007

\begin{abstract}
The possibility to use additivity rule [1] for estimation of relative conformational energies of fluoro- and bromo-substituted alkanes is studied. The ability of quantum mechanical methods (HF and MP2) to estimate the additivity increments $E_{G}^{X Y}$ $\left(X, Y=\mathrm{CH}_{3}, \mathrm{~F}, \mathrm{Br}\right), E_{G T}^{X Y}, E_{G G}^{X Y}, E_{G G^{\prime}}^{X Y}(X=Y=\mathrm{F}, \mathrm{Br})$ of conformational energy is examined. The obtained results have been compared with available experimental data. It is shown that increments are sensitive to the method and basis set used. The arrangement of relative conformational energies for various conformers in the series of polysubstituted fluoro- and bromoalkanes obtained using additivity rule agrees both with experimental findings and quantum mechanical calculations. The results lead to the conclusion that it is possible to work out the quantum mechanically based additivity schemes for investigated compounds.
\end{abstract}

Keywords: additivity, conformational energies, fluoro- and bromoalkanes

PACS: $33.15 . \mathrm{Bh}$

\section{Introduction}

The needs to determine the relative conformational energies (RCE) in the large molecules meet considerable difficulties. One of the possible ways to overcome them is the possibility to express the conformation energy by the sum of the transferable contributions from the various conformational fragments and their sequences defined from the small molecules. The theoretical background for so-called additivity schemes for conformational energy applying the one electron density matrix formalism has been worked out in [1]. It results in the analytically obtained additivity rule

$$
\begin{aligned}
E^{\mathrm{conf}} & =E-E^{\mathrm{T}} \\
& =n_{G}^{X Y} E_{G}^{X Y}+n_{G G}^{X Y} E_{G G}^{X Y}+n_{G T}^{X Y} E_{G T}^{X Y}+\ldots,
\end{aligned}
$$

where $E$ denotes the total energy of the molecule in given conformation, $E^{\mathrm{T}}$ is total energy of the molecule in the lowest energy conformation, $E_{G}^{X Y}, E_{G G}^{X Y}, E_{G T}^{X Y}$, etc. are the additivity increments, $n$ is the number of segments in the given conformation, $X$ and $Y$ stand for substitutes. As the experimental values of conformational energies obtained for the first members of homologous series of haloalkanes reveal the considerable scatter, it is reasonable to use the quantum mechanical calculations for estimation of the additivity increments. In our previous papers $[2,3]$ the results obtained for n-alkanes and chloroalkanes showed a good transferability of increments as well as applicability of additivity rule for investigated compounds. The purpose of current research is to study the ability of quantum mechanical methods and the basis sets available to estimate the increments corresponding to the energies of separate conformational segments and their sequences for simple fluoro- and bromoalkanes as well as to verify the additivity rule for more complicated compounds.

\section{Calculation resources}

The calculations for fluoro- and bromoalkanes have been performed using the computational chemistry packages PC GAMESS version and GAMESS (US) [4]. The full geometry optimization was carried out by HF and MP2 methods with core orbitals frozen. For fluoroalkanes we used MP2 with two basis sets, 6-311G $(2 d, 2 p)$ and $6-311 \mathrm{G}(3 d 1 f, 3 p)$, approved for chloroalkanes in [3]. Unfortunately TZ basis sets are not available for bromine in our used GAMESS versions. Thus we were forced to replace them for 
bromoalkanes with DZ basis sets using for HF a 6-31G $(d)$ and for MP2 calculations a $6-31 \mathrm{G}(3 d 1 f, 3 p)$ basis set with polarization functions $d$ and $f$ not taken into account for bromine atoms. For comprising of the results obtained for both studied haloalkanes we additionally performed HF calculations using 6-31( $d$ ) basis set for fluoroalkanes.

\section{Additivity increments for fluoralkanes}

\subsection{Estimation of additivity increments corresponding to the conformational segments for fluoroalkanes}

The values of additivity increments have been calculated using the first members of homologous series of fluoroalkanes: 1-fluoropropane, 1,2-difluoroethane, and n-butane as the difference between total energies of molecules in gauche $(G)$ and anti $(A)$ conformations: $E_{G}-E_{A}=E_{G}^{X Y}\left(X=\mathrm{F}, Y=\mathrm{CH}_{3}, X=Y=\mathrm{F}\right.$, and $X=Y=\mathrm{CH}_{3}$ ).

\subsubsection{1-fluoropropane}

The experimental data for 1-fluoropropane are available in liquid and vapour phase. Enthalpy differences obtained most recently in krypton and xenon solutions are $0.30 \pm 0.02$ and $0.28 \pm 0.01 \mathrm{kcal} / \mathrm{mol}$ respectively with gauche conformer of 1-fluoropropane being more stable than anti [5]. As the conformers have the similar dipole moments, the obtained result should be close to the value in vapour state. Indeed, the earlier measured gas phase data for $E_{G}-E_{A}$ range from $-0.35 \pm 0.03$ [6] to $-0.47 \pm 0.31 \mathrm{kcal} / \mathrm{mol}$ [7].

Theoretical estimates -0.01 and $-0.16 \mathrm{kcal} / \mathrm{mol}$ obtained using HF and LMP2 calculations with extended cc-pVTZ $(-f)$ basis set [8] respectively have the correct sign, but demonstrate large discrepancy with experimental data in value. Recent calculations of energy difference $E_{G}-E_{A}$ performed in [9] at $\mathrm{HF}, \mathrm{MP} 2$, and B3LYP levels using DZ and TZ basis sets show the energy of gauche form being lower than anti (Table 1). Moreover, the HF and B3LYP give the best agreement with experimental data when DZ basis set is used with the minimal number of polarization functions included. The enlargement of basis set degrades the results whereas MP2 calculations give the possibility to improve relative conformational energy value by extension to TZ basis set especially when diffuse functions are included.

In the present paper for the estimation of energy increment $E_{G}^{X Y}\left(X=\mathrm{F}, Y=\mathrm{CH}_{3}\right)$ the MP2 method
Table 1. RCE $\left(E_{G}-E_{A}\right)$ of 1-fluoropropane [9] calculated using various methods and basis sets: (A) polarization and (B) diffusion and polarization functions taken into account.

\begin{tabular}{lcc}
\hline \multirow{2}{*}{$\begin{array}{l}\text { Method and main atomic } \\
\text { basis set }\end{array}$} & \multicolumn{2}{c}{$\mathrm{RCE}(\mathrm{kcal} / \mathrm{mol})$} \\
\cline { 2 - 3 } HF/6-31G $(d)$ & -0.28 & $(\mathrm{~B})^{*}$ \\
\hline $\mathrm{HF} / 6-311 \mathrm{G}(d)$ & -0.24 & -0.06 \\
$\mathrm{~B} 3 \mathrm{LYP} / 6-31 \mathrm{G}(d)$ & -0.37 & -0.09 \\
$\mathrm{~B} 3 \mathrm{LYP} / 6-311 \mathrm{G}(d)$ & -0.42 & -0.16 \\
MP2/6-31G $(d)$ & -0.59 & -0.38 \\
MP2/6-311G $(d)$ & -0.48 & -0.36 \\
\hline${ }^{*} s$ and $p$ diffusion functions on heavy atoms $(\mathrm{C}$ \\
and F) included.
\end{tabular}

has been chosen with two different basis sets selected above for chloroalkanes [3]: 6-311G $(2 d, 2 p)$ and $6-311 \mathrm{G}(3 d 1 f, 3 p)$ with polarization functions of $d$ - and $f$-type on heavy atoms and of $p$-type on hydrogen atoms included.

The obtained results for $E_{G}^{X Y}$ are presented in Table 2. RCE value obtained using basis set 6-311G(3d1 $f$, $3 p)$ and corrected by zero point energy $\left(\Delta_{\mathrm{ZPE}}=0.07\right.$ [8]) is equal to $-0.40 \mathrm{kcal} / \mathrm{mol}$ and is within the scope of experimental data.

\subsubsection{1,2-difluoroethane}

The experimentally obtained results for 1,2-difluoroethanes show that gauche form has a lower energy than anti. This fact is called gauche effect and is characteristic only for fluoroethanes contrarily to the greater stability of the anti form for other 1,2-dihaloethanes. Gas phase data for $E_{G}-E_{A}$ energy lie within the -0.5 and $-2.0 \mathrm{kcal} / \mathrm{mol}$ limits. The most recent vibrational spectrum analysis gives the value $-0.8 \pm 0.1 \mathrm{kcal} / \mathrm{mol}$ [10] whereas the method based on the analysis of dielectric constant temperature dependence shows $-1.0 \pm 0.3 \mathrm{kcal} / \mathrm{mol}[11]$.

Theoretical evaluations obtained using HF/6-31G $(d)$ (Table 2) do not exhibit the presence of gauche effect, whereas HF and LMP2 with extended basis set (cc-pVTZ $(-f)$ ) reveal the preference of gauche form $(-0.13$ and $-0.55 \mathrm{kcal} / \mathrm{mol}$ respectively [8]). The calculations performed in [12] using MP2, G2/MP2, and B3LYP methods as well as TZ basis set with polarization and diffuse functions included demonstrate good agreement with experimental data, the $E_{G}-E_{A}$ value being approximately $-0.8 \mathrm{kcal} / \mathrm{mol}$.

In order to estimate the conformational energy increment $E_{G}^{X Y}(X=Y=\mathrm{F})$ the MP2 calculations of 1,2-difluoroethane using the both above chosen basis sets were performed. The results presented in Table 2 
Table 2. RCE and additivity increments ( $\mathrm{kcal} / \mathrm{mol})$ obtained from ab initio calculations of fluoroalkanes.

\begin{tabular}{ccccc}
\hline Fluoroalkanes & \multicolumn{4}{c}{$\mathrm{RCE}$ and additivity increments } \\
\cline { 2 - 4 }$\left(X=\mathrm{F}, Y=\mathrm{CH}_{3}\right)$ & $\mathrm{HF} / 6-31 \mathrm{G}(d)$ & \multicolumn{2}{c}{$\mathrm{MP} 2 / 6-311 \mathrm{G}$} & Exp. data \\
\cline { 3 - 4 } & & $(2 d, 2 p)$ & $(3 d 1 f, 3 p)$ & \\
\hline 1,2-difluoroethane & & & & \\
$E_{G}-E_{A}=E_{G}^{X X}$ & +0.45 & -0.52 & -1.06 & $-1.0 \pm 0.3[11]$ \\
& & & & $-0.8 \pm 0.1[10]$ \\
\hline 1-fluoropropane & & & & \\
$E_{G}-E_{A}=E_{G}^{X Y}$ & -0.28 & -0.59 & -0.47 & $-0.35 \pm 0.03[6]$ \\
\hline n-butane & & & & \\
$E_{G}-E_{A}=E_{G}^{Y Y}$ & 0.95 & 0.60 & 0.50 & $0.67 \pm 0.10[13]$ \\
\hline $1,3-$ difluoropropane & & & & \\
$E_{A A}-E_{G G}$ & 2.57 & 2.98 & 2.66 & $1.5 \pm 0.5[15]$ \\
$E_{G A}-E_{G G}$ & 1.09 & 1.39 & 1.23 & $1.1 \pm 0.4[15]$ \\
$E_{G G^{\prime}}-E_{G G}$ & 5.61 & 3.14 & 3.08 & $0.5 \pm 0.5[15]$ \\
\hline$E_{G X}^{X X}$ & -1.20 & -1.00 & -0.96 & - \\
$E_{G G}^{X X}$ & -2.01 & -1.80 & -1.72 & - \\
$E_{G G^{\prime}}^{X X}$ & 3.60 & 1.34 & 1.36 & - \\
\hline
\end{tabular}

show that the value of conformation energy $E_{G}-E_{A}$ converges to the experimental one $[10,11]$ when MP2 with basis set $6-311 \mathrm{G}(3 d 1 f, 3 p)$ is used. As the ZPE correction is equal to $-0.01 \mathrm{kcal} / \mathrm{mol}[8,12]$, it cannot considerably influence the calculated value.

\subsection{3. n-butane}

The most recent measurement of enthalpy difference between gauche and anti conformers of n-butane in vapour state using variable-low-temperature infrared spectra performed in [13] gives the value of $0.67 \pm$ $0.10 \mathrm{kcal} / \mathrm{mol}$. The results of theoretical calculations $[2,14]$ performed using $\mathrm{HF} / 6-31 \mathrm{G}^{*}$ and $\mathrm{HF} / 6-311 \mathrm{G}^{* *}$ overestimate the RCE value $(0.95 \mathrm{kcal} / \mathrm{mol})$ irrespective of the basis set used. The RCE values obtained by MP2/6-31G* [2] and MP2 /6-311G** single point calculations [14] are equal to 0.72 and $0.59 \mathrm{kcal} / \mathrm{mol}$ respectively. The estimated values of $E_{G}^{Y Y}\left(Y=\mathrm{CH}_{3}\right)$ increment together with calculations of fluoroalkanes are presented in Table 2 .

\subsection{Estimation of additivity increments corresponding to the sequences of conformational segments for fluoroalkanes}

For evaluation of additivity increments corresponding to the sequences of conformational segments we used HF/6-31G $(d)$ and the second order Möller-Plesset perturbation theory with two basis sets chosen above: $6-311 \mathrm{G}(3 d 1 f, 3 p)$ and $6-311 \mathrm{G}(2 d, 2 p)$. It gave the opportunity to achieve the optimal agreement between the obtained increment values on the same level of calculations. Inasmuch as the ZPE corrections do not significantly change the conformational energy value for all investigated cases, for further study of larger chloroalkanes from the practical point of view it seems reasonable to omit the calculations of ZPE.

The calculations of $G G, G G^{\prime}, G A$, and $A A$ forms of 1,3-difluoropropane (Fig. 1) give the possibility to estimate the energy increments $E_{G G}^{X X}, E_{G T}^{X X}$, and $E_{G G^{\prime}}^{X}$. As follows from Eq. (1), $E_{G T}^{X X}=E_{G A}-E_{A A}-E_{G}^{X Y}$, $E_{G G}^{X X}=E_{G G}-E_{A A}-2 E_{G}^{X Y}$, and $E_{G G^{\prime}}^{X}=E_{G G^{\prime}}-$ $E_{A A}-2 E_{G}^{X Y}\left(X=\mathrm{F}, Y=\mathrm{CH}_{3}\right)$, where $E_{G A}, E_{A A}$, $E_{G G}, E_{G G^{\prime}}$ are the total energies of corresponding conformers. Our calculations show that the $G G$ form has the lowest energy. The obtained MP2 results for RCE presented in Table 2 demonstrate good agreement with experimental data obtained from the gas phase electron diffraction [15]. However, experimental values showing an exceptionally low energy of $G G^{\prime}$ form raise some doubts.

It should be noted that both increments $E_{G G}^{X X}$ and $E_{G T}^{X X}$ are negative and consequently are lowering the value of the conformational energy. Vice versa, the additivity increment $E_{G G^{\prime}}^{X X}$ has a destabilizing character. The discussed increments are calculated for two selected basis sets. They are less sensitive to the basis set size than the ones corresponding to conformational segments.

HF/6-31G $(d)$ overestimates stabilization $\left(E_{G G}^{X X}\right.$ and $E_{G T}^{X X}$ increments) and destabilization $\left(E_{G G^{\prime}}^{X X}\right.$ increment) effects. 


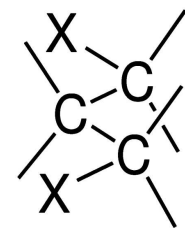

$\mathrm{AA}$

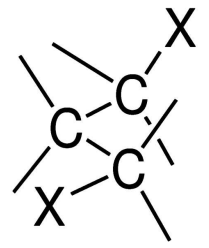

$A G$

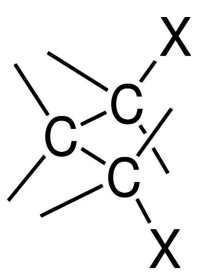

$\mathrm{GG}$

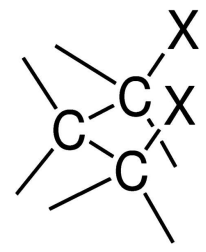

GG'

Fig. 1. Conformations of 1,3-dihalopropane ( $X=\mathrm{F}, \mathrm{Br})$.

\section{Additivity increments for bromoalkanes}

\subsection{Estimation of additivity increments corresponding to the conformational segments for bromoalkanes}

Similarly as in the case of fluoroalkanes the values of additivity increments for bromoalkanes have been calculated using the first members of homologous series of bromoalkanes 1-bromopropane and 1,2-dibromoethane as the difference between total energies of molecules in gauche $(\mathrm{G})$ and anti $(A)$ conformations: $E_{G}-E_{A}=$ $E_{G}^{X Y}\left(X=\mathrm{Br}, Y=\mathrm{CH}_{3}\right.$, and $\left.X=Y=\mathrm{Br}\right)$.

\subsubsection{1-bromopropane}

Limited experimental studies were carried out in vapour phase on the conformational stability of 1-bromopropane. The value of $0.11 \pm 0.03 \mathrm{kcal} / \mathrm{mol}$ was reported in [6] obtained from the far infrared data with gauche form being a stabler conformer. The variable temperature study of the infrared spectra of 1-bromopropane dissolved in liquid xenon was carried out most recently and the enthalpy difference $0.20 \pm 0.02 \mathrm{kcal} / \mathrm{mol}[16]$ was reported to confirm the stability of gauche form.

The results of extensive theoretical calculations $[9,16]$ performed using HF, MP2, and B3LYP methods with different basis sets are summarized in Table 3. One can notice that the best agreement with experimental data is obtained using $\mathrm{HF} / 6-31 \mathrm{G}(d)$ and B3LYP/6-31G $(d) / / \mathrm{HF} / 6-31 \mathrm{G}(d)$. The extension of basis set to $\mathrm{TZ}$ or inclusion of the diffuse functions in $\mathrm{HF}$ or B3LYP calculation degrades the results. It is also evident that MP2/6-31G $(d)$ overestimates the stability of gauche conformer. On the other hand, the high level MP2 calculations performed using 6-311G $(2 d, 2 p)$ basis set with diffuse functions enables one to obtain an agreement with experimental data.

As mentioned above, in the present paper the energy increment $E_{G}^{X Y}\left(X=\mathrm{Br}, Y=\mathrm{CH}_{3}\right)$ has been calculated using $\mathrm{HF} / 6-31 \mathrm{G}(d)$ and $\mathrm{MP} 2 / 6-31 \mathrm{G}(3 d 1 f, 3 p)$. The results (Table 4) show that HF underestimates $G$ form stability while MP2 overestimates it.
Table 3. RCE $\left(E_{G}-E_{A}\right)$ of 1-bromopropane calculated using various methods and basis sets: (A) polarization and (B) diffusion and polarization functions taken into account.

\begin{tabular}{lcc}
\hline Method and main atomic & \multicolumn{2}{c}{$\mathrm{RCE}(\mathrm{kcal} / \mathrm{mol})$} \\
\cline { 2 - 3 } basis set & $(\mathrm{A})$ & $(\mathrm{B})^{*}$ \\
\hline $\mathrm{HF} / 6-31 \mathrm{G}(d)$ & $-0.07[9,16]$ & $0.96[9]$ \\
$\mathrm{HF} / 6-311 \mathrm{G}(d)$ & $0.43[9]$ & $0.48[9]$ \\
\hline $\mathrm{B} 3 \mathrm{LYP} / 6-31 \mathrm{G}(d) / / \mathrm{HF} / 6-31 \mathrm{G}(d)$ & $-0.23[9]$ & $0.76[9]$ \\
$\mathrm{B} 3 \mathrm{LYP} / 6-311 \mathrm{G}(d) / / \mathrm{HF} / 6-311 \mathrm{G}(d)$ & - & $0.25[9]$ \\
\hline $\mathrm{MP} 2 / 6-31 \mathrm{G}(d)$ & $-0.52[9,16]$ & $0.60[9]$ \\
$\mathrm{MP} 2 / 6-311 \mathrm{G}(d)$ & $0.07[9], 0.02[16]$ & - \\
$\mathrm{MP} 2 / 6-311 \mathrm{G}(2 d, 2 p)$ & - & $-0.05[16]$ \\
\hline
\end{tabular}

* $s$ and $p$ diffusion functions on heavy atoms $(\mathrm{C}$ and $\mathrm{Br})$ included.

\subsubsection{1,2-dibromoethane}

The effect of temperature on the structure and composition of the rotational conformers of 1,2-dibromoethane has been studied by gas phase electron diffraction [17]. The energy difference $E_{G}-E_{A}$ was obtained being equal to $2.20 \pm 0.14 \mathrm{kcal} / \mathrm{mol}$ and the geometry of anti form was reported as well. Calculations performed in $[18,19]$ using G2/MP2 method led to the value $1.95 \mathrm{kcal} / \mathrm{mol}$.

The results obtained in the present paper for $E_{G}^{X X}$ $(X=\mathrm{Br})$ on $\mathrm{HF} / 6-31 \mathrm{G}(d)$ level are in perfect agreement with experimental data while the MP2/6-31G calculations give about two times lower value (Table 4).

\subsection{Estimation of additivity increments corresponding to the sequences of conformational segments for} bromoethanes

The calculations performed for $G G, G G^{\prime}, G A$, and $A A$ forms of 1,3-dibromopropane give the possibility to estimate the energy increments $E_{G G}^{X X}, E_{G T}^{X X}$, and $E_{G G^{\prime}}^{X X}$ using formulas presented in 3.2.

The calculations performed show the $G G$ form having the lowest energy, like in fluoroalkanes. The analysis of results obtained (Table 4) show that MP2/6-31G( $3 d 1 f, 3 p)$ overestimates RCE values while $\mathrm{HF} / 6-31 \mathrm{G}(d)$ results are in perfect agreement with 
Table 4. RCE and additivity increments $(\mathrm{kcal} / \mathrm{mol})$ obtained from ab initio calculations of bromoalkanes.

\begin{tabular}{cccc}
\hline Bromoalkanes & \multicolumn{3}{c}{ RCE and additivity increments } \\
\cline { 2 - 4 }$\left(X=\mathrm{Br}, Y=\mathrm{CH}_{3}\right)$ & $\mathrm{HF} / 6-31 \mathrm{G}(d)$ & $\mathrm{MP} 2 / 6-31 \mathrm{G}(3 d 1 f, 3 p)$ & Exp. data \\
\hline 1,2-dibromoethane & & & \\
$E_{G}-E_{A}=E_{G}^{X X}$ & 2.16 & 1.07 & $2.20 \pm 0.14[17]$ \\
\hline 1-bromopropane & & & \\
$E_{G}-E_{A}=E_{G}^{X Y}$ & -0.02 & -0.47 & $-0.11 \pm 0.03[6]$ \\
\hline 1,3 -dibromopropane & & & \\
$E_{A A}-E_{G G}$ & 1.69 & 2.57 & $1.6 \pm 0.5[20]$ \\
$E_{G A}-E_{G G}$ & 0.95 & 1.59 & $0.9 \pm 0.2[20]$ \\
$E_{G G^{\prime}}-E_{G G}$ & 5.04 & 4.59 & $\sim 3[20]$ \\
\hline$E_{G X}^{X X}$ & -0.72 & -0.51 & - \\
$E_{G G}^{X X}$ & -1.65 & -1.63 & - \\
$E_{G G^{\prime}}^{X X}$ & 3.39 & 2.96 & - \\
\hline
\end{tabular}

experimental data [20]. Therefore one can conclude $\mathrm{HF} / 6-31 \mathrm{G}(d)$ being sufficiently good for larger bromoalkanes. It should be noted that both increments $E_{G G}^{X X}$ and $E_{G T}^{X X}$ are negative and consequently lowering the value of the conformational energy. Vice versa, the additivity increment $E_{G G^{\prime}}^{X X}$ has an extremely destabilizing character.

The $E_{G G}^{X X}$ increments related to the sequence of conformational segments $G$ were calculated using two different methods and basis sets. The obtained results show that $E_{G G}^{X X}$ are less sensitive to the method and basis set size than additivity increment related to the conformational segment $E_{G}^{X X}$ (see Table 4).

\section{Verification of additivity rule for fluoro- and bromoalkanes}

The molecules of 1,2-difluoro-, 1,2,3-trifluoropropane, 2-fluoro-, and 2,3-difluorobutane were used in order to check the transferability of additivity increments. The relative energies of different conformers of an individual molecule calculated using the additivity rule (1) and direct MP2/6-311G $(3 d 1 f, 3 p)$ as well as experimental data available are presented in Table 5.

The arrangement of calculated conformational energies for 1,2-difluoropropane (Fig. 2) in both cases is identical, i. e. $G^{-}$is the lowest while $A$ is the highest energy forms, however, the particular magnitudes of RCE are different. The comparison with experimental data is not available because of absence of the latter.

The arrangement of rotamers $A A, A G, G A, G G$, $G G_{+}^{\prime}, G G_{-}^{\prime}$ of 1,2,3-trifluoropropane (Fig. 2) on the energy scale shows $G G$ conformer being the lowest energy form of the molecule. Other low energy conformers as follows from Table 5 are $G A, A G$, and $A A$. a)<smiles>[X]C1(C)CC2(C)CC1CC2C</smiles>

$\mathbf{G}^{+}$

b)

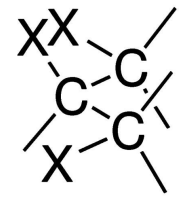

AA

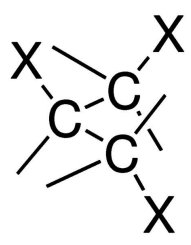

GG

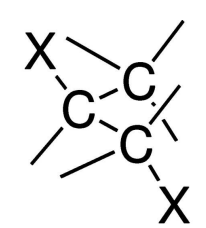

A

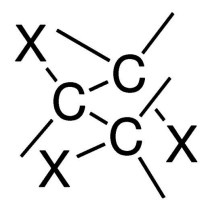

AG

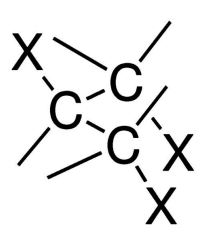

GG.'

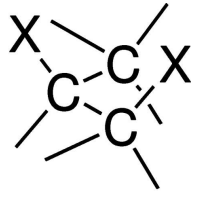

$\mathbf{G}^{-}$

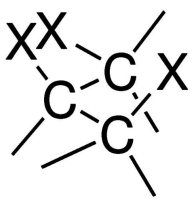

GA

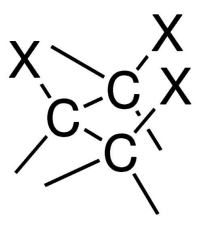

$\mathbf{G G}_{+}^{\prime}$
Fig. 2. Conformations of (a) 1,2-dihalopropane ( $X=\mathrm{F}, \mathrm{Br})$, (b) 1,2,3-trihalopropane $(X=\mathrm{F}, \mathrm{Br})$.

Direct MP2 calculations as well as those performed using formula (1) with increments calculated on the same level give the identical arrangement of conformers on the energy scale.

The molecule of 2-fluorobutane has $G^{+}, G^{-}$, and $A$ forms (Fig. 3). In accordance with direct calculations as well as additivity rule, the lowest energy form is found to be $A$. The arrangement of RCE for both cases is identical whereas the particular magnitude of $G^{-}$energy is overestimated when using additivity rule. 
Table 5. RCE values for haloalkanes calculated both using quantum mechanical methods and additivity rule as well as obtained experimentally.

\begin{tabular}{|c|c|c|c|c|c|c|}
\hline \multirow[t]{2}{*}{ Haloalkanes } & \multicolumn{3}{|c|}{$\begin{array}{c}\text { Fluoroalkanes } \\
\mathrm{MP} 2 / 6-311 \mathrm{G}(3 d 1 f, 3 p)\end{array}$} & \multicolumn{3}{|c|}{$\begin{array}{c}\text { Bromoalkanes } \\
\mathrm{HF} / 6-31 \mathrm{G}(d)\end{array}$} \\
\hline & Calc. & Eq. (1) & Exp. & Calc. & Eq. (1) & Exp. \\
\hline \multicolumn{7}{|l|}{ 1,2-dihalopropane } \\
\hline$E_{G^{+}}-E_{A}$ & 0.001 & -0.59 & - & 2.30 & 2.18 & $1.3 \pm 0.6[21]$ \\
\hline$E_{G^{-}}-E_{A}$ & -0.32 & -1.06 & - & 2.11 & 2.16 & $1.9 \pm 0.6[21]$ \\
\hline \multicolumn{7}{|l|}{ 1,2,3-trihalopropane } \\
\hline$E_{A G}-E_{G G}$ & 0.85 & 1.25 & - & 0.95 & 0.95 & $1.5 \pm 0.4[22]$ \\
\hline$E_{G A}-E_{G G}$ & 0.50 & 0.17 & - & 2.79 & 3.11 & $1.5 \pm 0.4[22]$ \\
\hline$E_{A A}-E_{G G}$ & 1.89 & 1.61 & - & 3.79 & 3.85 & - \\
\hline$E_{G G_{+}^{\prime}}-E_{G G}$ & 3.52 & 4.14 & - & 3.57 & 2.88 & - \\
\hline$E_{G G_{-}^{\prime}}^{+}-E_{G G}$ & 3.33 & 2.02 & - & 7.20 & 7.20 & - \\
\hline \multicolumn{7}{|l|}{ 2-halobutane } \\
\hline$E_{G^{+}}-E_{A}$ & 0.56 & 0.50 & - & 0.79 & 0.95 & - \\
\hline$E_{G^{-}}-E_{A}$ & 0.58 & 0.97 & - & 0.80 & 0.97 & - \\
\hline \multicolumn{7}{|l|}{ 2,3-dihalobutane } \\
\hline$E$ isomer $E_{G^{+}}-E_{A}$ & 0.62 & -0.09 & $E_{G}<E_{A}[23]$ & 1.84 & 3.13 & $1.6[24]$ \\
\hline$T$ isomer $E_{G^{+}}-E_{A}$ & 0.33 & 1.56 & - & -1.54 & -1.21 & $-1.6[25]$ \\
\hline$E_{G^{-}}-E_{A}$ & 0.77 & 1.44 & - & 1.79 & 0.99 & - \\
\hline
\end{tabular}

a) $x y$

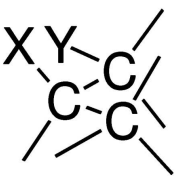

A

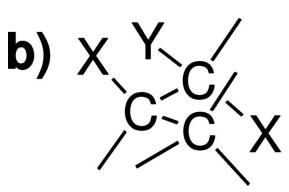

A

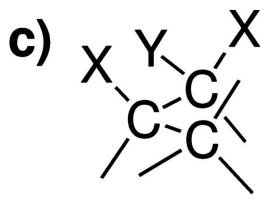

A

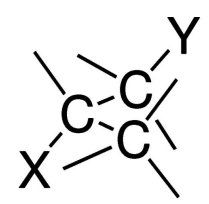

G-

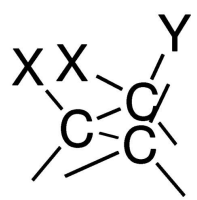

$\mathrm{G}^{+}$

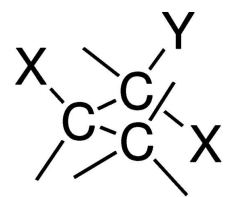

$\mathbf{G}^{+}$

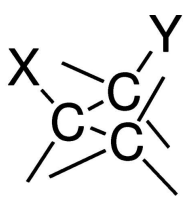

$\mathbf{G}^{+}$

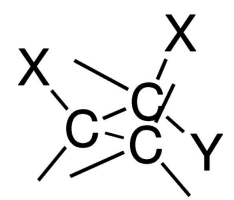

G-

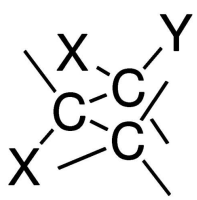

$\mathbf{G}^{-}$
Fig. 3. Conformations of (a) 2-halobutane $(X=\mathrm{F}, \mathrm{Br})$, (b) 2,3-dihalobutane $\left(X=\mathrm{F}, \mathrm{Br}, Y=\mathrm{CH}_{3}\right) E$ isomer, (c) 2,3-dihalobutane $T$ isomer.

NMR experiments show [23] that isomer $E$ of 2,3 difluorobutane in solution is predominantly in gauche conformation $\left(G^{+}\right.$and $G^{-}$being fully degenerate), while isomer $T$ either has all possible staggered conformers populated or only the two conformers with fluorine atoms in the gauche position (Fig. 3(c), confor- mations $A$ and $G^{-}$). As the gas phase data may lead to different conformational energies, we have performed direct MP2 calculations. The results show that $A$ is the lowest energy conformation for both $E$ and $T$ isomers. The application of Eq. (1) leads to the analogous result, but $A$ and $G^{+}$forms of $E$ isomer appear being degenerate. $G^{+}$and $G^{-}$forms of $T$ isomer are almost degenerate (energy difference is $0.12 \mathrm{kcal} / \mathrm{mol}$ ).

As the best results for conformational energies of investigated above bromoalkanes have been obtained at HF/6-31G $(d)$ level (Table 4), the verification of additivity rule for bromoalkanes has been tested using mentioned direct calculations for 1,2-dibromo-, 1,2,3tribromopropane, 2-bromo-, and 2,3-dibromobutane.

The arrangement of calculated conformational energies for 1,2-dibromopropane (Fig. 2) obtained both by direct calculations and additivity rule is identical and shows form $A$ being the lowest energy conformer as well as $G^{+}$and $G^{-}$forms not considerably differing in values. Experimental measurements reported in [21] confirm form $A$ being the lowest energy conformer. However, the large experimental uncertainty does not allow one to give unambiguously the answer which conformer $\left(G^{+}\right.$or $\left.G^{-}\right)$is lower on the energy scale.

HF/6-31G $(d)$ calculations for $A A, A G, G A, G G$, $G G_{+}^{\prime}$, and $G G_{-}^{\prime}$ rotamers of 1,2,3-tribromopropane (Fig. 2) indicate $G G$ being the lowest energy form. This is in agreement with experimental data [22]. The 
results presented in Table 5 reveal the next low energy form being $A G$ with the close to the experimental RCE value. It seems that the coincidence of experimentally obtained $A G$ and $G A$ energy values is scarcely probable when taking into account their large uncertainties. Our calculations show $A A, G G$, and $G G_{-}^{\prime}$ being the high energy forms with RCE value of about $3 \mathrm{kcal} / \mathrm{mol}$. However, the RCE obtained using the additivity rule and direct calculations differ in their values. On the other hand, the RCE values found for $A A$ and $G G_{+}^{\prime}$ conformers perfectly corroborate the additivity rule.

The $A$ conformer of 2-bromobutane (Fig. 3) was found as being of the lowest energy (Table 5). The degenerate energies of $G^{+}$and $G^{-}$forms for both kinds of calculations show coincidence. Unfortunately the experimental data are not available.

The experimental results for $E$ isomer of 2,3-dibromobutane show $A$ being the low energy form what is in agreement with our calculation results. For $T$ isomer the only available experimental data in liquid phase shows $G^{+}$being the lowest energy form. Direct calculations as well as calculations made using additivity rule (Eq. (1)) affirm the experimental result and show the $G^{-}$form being the high energy conformer.

\section{Conclusions}

The obtained results for fluoro- and bromoalkanes show that the calculated additivity increments obtained using various computational methods give different values for additivity increments $E_{G}^{X Y}, E_{G T}^{X Y}, E_{G G}^{X X}$, and $E_{G G^{\prime}}^{X X}$. The value of the given increment depends on the method and bases set used. Thus, for fluoroalkanes the HF/6-31G $(d)$ does not reflect gauche effect and overestimates the values of segmental increments. The appropriate values for segmental increments can be obtained only in sufficiently wide basis sets when electron correlation is scored up. Meanwhile for bromoalkanes the HF/6-31G $(d)$ reveals itself as fairly suitable approximation giving the results comparable with experimental data.

The study demonstrates that obtained increment values are transferable and correctly reflect the arrangement of different conformational configurations of the molecule on the energy scale. Consequently, it can be concluded that the quantum mechanical methods can be successfully used for determination of the additivity increments necessary in systematic additivity approach.

\section{References}

[1] D. Šatkovskienè, Int. J. Quant. Chem. 91, 5 (2003).

[2] R. Jankauskas, P. Pipiraité, and D. Šatkovskienè, Lithuanian J. Phys. 42, 87 (2002).

[3] D. Šatkovskienè, P. Pipiraité, R. Jankauskas, and J. Šulskus. Lithuanian J. Phys. 44, 27 (2004).

[4] M.W. Schmidt, K.K. Baldridge, J.A. Boatz et al., J. Comput. Chem. 14, 1347 (1993); A.A. Granovsky, http://classic.chem.msu.su/ gran/gamess/.

[5] G.A. Guirgis, X. Zhu, and J.R. Durig, Struct. Chem. 10, 445 (1999).

[6] J.R. Durig, S.E. Godbey, and J.F. Sullivan, J. Chem. Phys. 80, 5983 (1984).

[7] E. Hirota, J. Chem. Phys. 37, 283 (1962).

[8] R.A. Friesner, R.B. Murphy, M.D. Beachy, M.N. Ringnalda, W.T. Pollard, B.D. Dunietz, and Y. Cao, J. Phys. Chem. A 103, 1914 (1999).

[9] M.R. Helal, Y.A. Yousef, and A.T. Afaneh, J. Comput. Chem. 23, 966 (2002).

[10] J.R. Durig, J. Liu, T.S. Little, and V.F. Kalashinsky, J. Phys. Chem. 96, 8224 (1992).

[11] A.R.H. Goodwin and G. Morrison. J. Phys. Chem. 96, 5521 (1992).

[12] K. B. Wiberg, T.A. Keith, M.J. Frisch, and M.A. Murcko, J. Phys. Chem. 99, 9072 (1995).

[13] W.A. Herrebout, B.J. van der Veken, A. Wang, and J.R. Durig, J. Phys. Chem. 99, 578 (1995).

[14] R.F. Frey, M. Cao, S.Q. Newton, and L. Schafer, J. Mol. Struct. 258, 99 (1993).

[15] P. Klaboe, D.L. Powell, R. Stolevik, and O. Vorren, Acta Chem. Scand. A 36, 471 (1982).

[16] J.R. Durig, X. Zhu, and S. Shen, J. Mol. Struct. 570, 1 (2001).

[17] L. Fernholt and K. Kveseth, Acta Chem. Scand. A 32, 63 (1978).

[18] Z.-H. Li, K.V. Fan, and M.W. Wong, J. Phys. Chem. A 105, 10890 (2001).

[19] C. Trindle, P. Crum, and K. Douglass, J. Phys.Chem. A 107, 6236 (2003).

[20] P.E. Farup and R. Stolevik, Acta Chem. Scand. A 28, 680 (1974).

[21] S.H. Shei and R. Stolevik, J. Mol. Struct. 128, 171 (1985).

[22] R. Stolevik, Acta Chem. Scand. A 28, 299 (1974).

[23] G. Angelini, E. Gavuzzo, A.L. Segre, and M. Speranza, J. Phys. Chem. 94, 8762 (1990).

[24] R.J. Abraham, J. Phys. Chem. 73, 1192 (1969).

[25] S. Winstein and R.E. Wood, J. Am. Chem. Soc. 62, 548 (1940). 


\title{
KVANTMECHANINIS FLUORO IR BROMO ALKANU KONFORMACINĖS ENERGIJOS ADITYVUMO TYRIMAS
}

\author{
R. Jankauskas, P. Pipiraitè, D. Šatkovskienè
}

Vilniaus universitetas, Vilnius, Lietuva

\section{Santrauka}

Išnagrinèta galimybė panaudoti [1] darbe gautą adityvumo taisyklę, ivvertinant alkanų su fluoro ir bromo pakaitalais reliatyviąsias konformacines energijas. Tuo tikslu išnagrinètos HF ir MP2 kvantmechaniniu metodu galimybès apskaičiuoti adityviuosius konformacinès energijos prieaugius $E_{G}^{X Y}\left(X, Y=\mathrm{CH}_{3}, \mathrm{~F}, \mathrm{Br}\right)$ ir $E_{G T}^{X Y}$, $E_{G G}^{X Y}, E_{G G^{\prime}}^{X Y}(X=Y=\mathrm{F}, \mathrm{Br})$. Gauti rezultatai palyginti su literatūroje pateikiamais eksperimentiniais duomenimis. Parodyta, kad prieaugių vertès priklauso nuo panaudoto metodo ir pasirinktos ba- zès. Išnagrinètų fluoro ir bromo alkanų su keliais pakaitalais įvairių konformerų reliatyviujjų energijų tarpusavio išsidèstymas, gautas naudojant adityvumo taisyklę, atitinka eksperimento duomenis ir tiesioginio kvantmechaninio konkrečios molekulès skaičiavimo rezultatus. Tai rodo, kad konformaciniu prieaugių vertès yra taikytinos ir sudètingiems haloalkanams. Gautieji rezultatai leidžia daryti išvadą, kad galima sukurti kvantmechaniškai pagrịstas konformacinès energijos adityvumo schemas ištirto tipo junginiams. 